\section{Workshop on medical writing}

There are still a few vacancies for the $B M \mathcal{F}$ workshop on problems with medical writing at the Birmingham Medical Institute on 1 July. Those wishing to participate should be willing to submit in advance a paper for discussion and tuition and should apply, with a cheque for $£ 20$, to the Editor, British Medical Journal, BMA House, Tavistock Square, London WC1H 9JR.

\section{Alan Edwards Memorial Fund}

The money collected for the above fund (see BMF, 22 May 1976, p 1288) totalled $£ 2098$. This was passed to the British Association of Surgical Oncology for an annual essay prize for young surgeons.

\section{COMING EVENTS}

"Nutritional aspects of gastroenterology"Symposium, 30 June-1 July, London. Details from the dean of postgraduate studies, Sr Mark's Hospital, City Road, London EC1V 2PS. (Te 01-253 1050.)

Whipps Cross Hospital-Details and copies of the programme to 30 August are now available from the Medical Education Centre, Whipps Cross Hospital, London E11. (Tel 01-539 5522 ext 310.) Winchester and Central Hampshire Postgraduate Medical Centre-Details and copies of the programme May to August 1977 are now available from the Centre, Hampshire County Hospital, Winchester. (Tel Wincinester 63535 ex 422.)

\section{SOCIETIES AND LECTURES}

For attending lectures marked * a fee is charged or a ticket is required. Applications should be made first to the institution concerned.

\section{Monday, 30 May}

INSTITUTE OF OBSTETRICS AND GyNaECology-A Queen Charlotte's Hospital, 4.30 pm, Dr M de Swiet

\section{Tuesday, 31 May}

Royal Free Hospital-1 pm, Dr F J Dudley (Australia): Glucagon metabolism.

\section{Wednesday, 1 June}

Institute OF PsYchiatry-5.30 pm, Dr M $\mathrm{F}$ Carruthers: Heart attack: egg or ego ?
MFDICO-PhARMACEUTICAL ForUM-At Royal Society of Medicine, 3.30 pm, statutory meeting: "The surviva of medical journals.

ROYAL COLLEGE OF SURGeONS OF ENGLAND-At Royal Victoria Infirmary, Newcastle, $4 \mathrm{pm}$, Hunterian ecture by Professor $\mathrm{M} \mathrm{H}$ Thompson: Histamine $\mathrm{H}$ receptor antagonists and peptic ulcer disease. $5.30 \mathrm{pm}$ Harris and Gale lecture by $\mathrm{Mr}$ C Britton: The patho-physiological sequelae of peptic ulcer surgery.
ROYAL FREE HOSPITAL - 5 pm, Dr R Hecker (Adelaide): Cimetidine and duodenal ulcer. ROYAL POSTGRADUATE MEDICAL SCHOOL-11.45 am,
Professor C Alleyene (West Indies):

UNIVERSITY OF OXFORD-At John Radcliffe Hospital,
$4 \mathrm{pm}, \mathrm{Mr}$ Peter Anderson: Sexual attitudes of $4 \mathrm{pm}, \mathrm{Mr}$ Peter Anderson: Sexual attitudes of
undergraduates-preliminary report of Oxford study.

\section{Thursday, 2 June}

Oncology Club-At Guy's Hospital, 6.30 pm, Dr R Rubens: Prospects in the treatment of breast cancer T MARY's HosPITAL MEDICAL SCHOOL- 5.15 pm
Aleck Bourne lecture by Miss Aileen Dickins: The care of the older pregnant woman.

\section{BMA NOTICES}

\section{Diary of Central Meetings}

JUNE

2 Thurs Joint Agenda Committee, 2 pm.

mittee (7 Drumsheugh Gardens, Edinburgh

$8 \mathrm{Wed}$
9 Thurs Organisation Committee, 10.15 am.

9 Thurs New Consultant Contract Working Party

10 Fri Executive Subcommittee (CCCM), $10.30 \mathrm{am}$.

\section{Division Meetings to be Held}

Members proposing to attend meetings marked * are concerned.

Bromley-At Farnborough Hospital, Thursday,

June, $8.30 \mathrm{pm}$, agm.
Durham-At Dryburn Hospital, Monday, $30 \mathrm{May}$, 8.30 pm, Mr J B Secrett: "Washington Wildfowl Refuge."' (Preceded by supper, 7 for 7.30 pm.* Guests are invited.)

Leicestershire and Rutland-At Overstone Solarium, Saturday, 4 June, 7.30 for $8 \mathrm{pm}$, medical

Manchester-At Boyd House, Tuesday, 31 May, 8 for $8.30 \mathrm{pm}$, Dr P H Smith: "Assessment of a new (Supper provided.)

North and South Camden Divisions-At Kenwood House, Thursday, 2 June, 7.15 for $8 \mathrm{pm}$, Jubilee dinner.* (Guests are welcome.)

Northern Region-At Crest Motel, Carlisle, Monday, 30 May, 7.15 for $7.30 \mathrm{pm}$, council meeting. North-west Essex-At Princess Alexandra Hospital. Thursday, 2 June, 8 for $8.30 \mathrm{pm}$, agm.

South Middlesex-At Queen Mary Sailing Club, South, 2 June, $7.30 \mathrm{pm}$, supper dance.* Thursday, 2 June, $7.30 \mathrm{pm}$, agm followed by annual Wirral-At Clatterbridge Hospital, Thursdav, 2
inner. June, $8 \mathrm{pm}$, meeting to discuss agenda for ARM.

\section{UNIVERSITIES AND COLLEGES}

\section{CAMBRIDGE}

MD-W A D Griffiths, C J Oon, D J Powell-Jackson. SOUTHAMPTON

The title of reader in clinical epidemiology and community medicine has been conferred on Dr D J P Barker. LONDON

W P du Vivier, B J B Grant, A G Morgan. AS-JF Colin, A N Nicolaides.

ROYAL COLLEGE OF PHYSICIANS OF EDINBURGH

At a quarterly meeting of the college held on Thursday, 5 May, with the president, Dr R F Robertson, in the chair, Lillian $M$ Pickford and $R$ Van Furth were elect
Fellows under the Laws of the College, Cap II, 10 . Fellows under the Laws of the College, Cap II, 10 .
Dr Catriona Irvine was awarded a Hill Pattisontruthers bursary for 1977 .

The Medical Commission on Accident Prevention .

ROYAL COLLEGE OF PHYSICIANS OF

The following have been elected to fellowship of the The following have been elected to fellowship of the A Divaris, H Grusin, I F Hayali, I P Jaffe, I P Sparks, N C Begg, J H Deakin, J H Pratt-Johnson, R E Beamish, wood, Surg-Rear Admiral S G Rainsford, D'A Kok, wood, Surg-Rear Admiral S G Rainsford, D'A Kok, $F$ E Dische, Brenda D Van Leuven, $M$ J D Newman,
$P$ M Higgins, A R H Worssam, T C K Marr, Rosemary P M Higgins, A R H Worssam, T C K Marr, Rosemary A Cooper, D J Gudex, W B Hennessy, Katharine M
Dormandy, F H Burns, A J Goble, W M I Maxwell, R Slome, D J Attygalle, J H Allison, A D Forrest, P J Pinto, T H S Kirkland, I D Thomas, P Ebeling, R S Mibashan, R H Culpan, I R Ferguson, J M Duggan, J S Garfield, G A Hunter, V F Weinstein, L H Opie, $M$ Greenberg, M J Pritchard, KF F Schiller, Shelagh $M$ Tighe, J G Sloman, H B Griffith, E N Glick, P M Last, G Michell, M D Rawson, J M Costello, Rosemary
Stephens, P T Pickens, W D Stone, E E Jones, H J
Liebeschuetz, Valerie J Marrian, O H D Portsmouth, Liebeschuetz, Valerie J Marrian, O H D Portsmouth, Norris, K P Goldman, Betty L Priestley, H A Rees, R P Ashfield, N J B Evans, C J Goodwill, M R Lee,
M A Newton, G B w yatt, D C Fluck. C Tasman-Jones, E A Paykel, P L Boardman, J F Harrison, A C Ikeme, B A Latham, S M Rosen, A H Henderson, R Garnett, S D B Mohamed, J Perkins, B K Samtani, Mary Corbett, T P Ormerod, EKM Smith, R W Emmerson, $G$ I Nicholson, $M$ J Smith, G C Sutton, $M$ Thomas, G J Thorpe, E G Anderson, W I Austad. CI Burns-Cox, A R R Cain, J W H Doar, Margaret E R Stoneman, Shirley H W ray, D B Grant, J J F Hamblin, D H W
Kelly, A D Ferguson, T M Hayes, D M Hill, Elizabeth Kelly, A D Ferguson, T M Hayes, D M Hill, Elizabeth
A Hills, J K L Jones, M P Mahoney, N Peters, E B A Hills, J K L Jones, M P Mahoney, N Peters, E B
Raftery, I D B Rennie, Evan M Kohner, J P O'Loughlin, $G$ S Spathis, O H Amin, S S Bleehen, A K Brown G F Cohen, H L H Frankel, R L Himsworth, P J R B Sterling, J D Swales, J A Walker-Smith, A T Bevan K D Buchanan, P Cannon, F J Goodwin, C R M Prentice, G P Sechiari, P Sharpstone, Wing Commander G C Turner, E T Young, A S Abraham, T M Barratt, Rrackenridge, C K Connolly, B M Greenwood, M J G
Harrison, M W Kanan, A S McNeish, J W Paterson, L A Salako, A Seaton, R D H Boyd, J D Carroll, A C F Nonmure, C A E H Loehry, M W Moncrieff, T C J M H Buckler, J H Keen, B J Prout, P C Robertson, Rubenstein, W J Cunliffe, D Gardner-Medwin, A H L Ngu, B N C Prichard, R M McLellan, T-K Chan, R N Maini, G R Serjeant, C E Sissons, C W M Adams, J D Baum, D A Warrell, C Chantler, D Ogston, Anne G Ferguson, J O M Pobee, J C Crawhill, D L Davies, F J jakul, D J Kinloch, I MacIntyre, M Swash, W R Lee, G P McNicol, M Friedman, J Landon, E J L L Lowbury, McLeod, D C Morley, Elsie R Rue, I G Taylor, E D Williams

The following were elected fellows under Bye-Law 39(c)-N Islam, Group Captain $P$ Howard, A M Adelstein, B R Jones, J G Widdicombe, M Caplin,

The following were elected fellows under Bye-Law 39(b)-B G Alton, J A F Ambrose, J W Black, R M Gregory, J T Shepherd. The following were elected members under Bye-Law (d) - $R$ G Batey, F B Crimmins, A H Waters. 117-E A Barker, J R Clamp, A M Geddes, A Ghareeb, Ruth F Harris, R A Joske, A K Mant, J W Thompson.

\section{APPOINTMENTS}

Salford Area Health Authority (Teaching)-The following consultants have been appointed: $\mathrm{Mr}$ G G Mitchell (obste
(neurology).

\section{Corrections}

Advances in the treatment of kidney disease: An introduction

In this article by Dr J R Curtis (14 May, p 1270) under sub-heading "Peripheral neuropathy and chronic renal failure," the last sentence of the third paragraph should begin "Myo-inositol has recently attracted attention...

Annual Report of Council (Appendix VII: Amendment to the Second Schedule to the By-laws)

The sentence " 1 to be nominated by the Council of the British Dental Association" under nonvoting members of the General Medical Services Committee ( 7 May, p 1236) should be deleted and a new paragraph inserted which should read "1 representative appointed by the Council of the British Dental Association."

\section{From the CCHMS}

In the third paragraph of the report from the chairman ("From the CCHMS", 21 May, p 1368) "Nuffield Provincial Hospitals Trust" should read "Nuffield Nursing Homes Trust." We apologise for this error.

\section{Notice to authors}

When original articles and letters for publication are not submitted exclusively to the British Medical fournal this must be stated. For detailed instructions to authors see page 6 of the issue dated 1 January 1977.

Correspondence on editorial business should be addressed to the Editor, British Medical fournal, BMA House, Tavistock Square, London WC1H 9JR. Telephone: 01-387 4499. Telegrams: Aitiology, London WC1. Communications will not be acknowledged unless a stamped addressed postcard or an international reply coupon is enclosed.

Authors wanting reprints of their articles should notify the Publishing Manager, BMA House, Tavistock Square, WC1H 9JR, on receipt of proofs.

\section{(C) British Medical Journal 1977}

All Rights Reserved. No part of this publication may be reproduced, stored in a retrieval system, or transmitted, in any form or by any means, electronic, mechanical, photocopying, recording or otherwise, without the prior permission of the British Medical fournal. 